\title{
OR11-005 - Mast cells respond to pathogen signals with IL-1ß
}

\author{
L Kraas $^{1 *}$, O Schmetzer ${ }^{1}$, K Krause $^{1}$, E Latz $^{2}$, M Maurer $^{1}$ \\ From 7th Congress of International Society of Systemic Auto-Inflammatory Diseases (ISSAID) \\ Lausanne, Switerland. 22-26 May 2013
}

\section{Introduction}

Mast cells, key effector cells of allergic and innate immune responses, have recently been reported to be an important source of IL- $1 ß$ in patients with autoinflammatory conditions such as cryopyrin-associated-periodic-fever syndromes (CAPS). CAPS patients show IL-1beta-driven systemic inflammation together with non-histamine dependent urticarial rash, which are caused by activating mutations of the inflammasome, a multiprotein oligomer responsible for the initiation of inflammatory responses to pathogens.

\section{Objectives}

To determine if mast cells can produce and release IL-1ß in response to pathogenic signals that target the inflammasomes NLRP3, NLRC4, or AIM2.

\section{Methods}

Peritoneal mast cells (PMCs) were obtained through lavage from adult ( $>8$ weeks) C57BL/6 mice and WBB6F1 Kit+/+ mice, purified via CD117+ bead selection ( $>96 \%$ purity) and cultured for 7-14 days. $10^{5}$ cells/well were primed with LPS (100ng/ml) for 15 hrs. Then the PMCs were stimulated with $10 \mu \mathrm{M}$ Nigericin (NLRP3), $5 \mathrm{mM}$ ATP (NLRP3), 100 $\mu$ M R837 (NLRP3) for $45 \mathrm{~min}$ or for 4 hours with $600 \mathrm{ng}$ Flagellin (NLRC4) transfected with DOTAP or $200 \mathrm{ng}$ polydAdT (AIM2) transfected with Lipofectamine. IL-1 beta production was measured in the supernatants by Elisa.

\section{Results}

PMCs produced significant amounts (mean \pm SEM) of IL-1ß upon stimulation with Nigericin $(467 \pm 41 \mathrm{pg} / \mathrm{ml})$, ATP $(152 \pm 88 \mathrm{pg} / \mathrm{ml}), \mathrm{R} 837(21 \pm 2 \mathrm{pg} / \mathrm{ml})$, Flagellin

${ }^{1}$ Dermatology and Allergy, Charité Universitätsmedizin Berlin, Berlin, Germany Full list of author information is available at the end of the article
$(245 \pm 44 \mathrm{pg} / \mathrm{ml})$ and polydAdT $(571 \pm 194 \mathrm{pg} / \mathrm{ml})$ as compared to no stimuli $(7,1 \pm 0,8 \mathrm{pg} / \mathrm{ml})$ only.

\section{Conclusion}

We show that mouse mast cells incubated with inflammasome activators produce significant amounts of IL- $1 ß$ ex vivo. Our data suggest that inflammasome-driven mast cell activation and subsequent IL- $1 ß$ production and release may importantly contribute to innate immune responses to pathogens.

\section{Competing interests}

None declared.

\section{Authors' details}

${ }^{1}$ Dermatology and Allergy, Charité Universitätsmedizin Berlin, Berlin, Germany. ${ }^{2}$ Institute of Innate Immunity, University Hospitals Bonn, Bonn, Germany.

Published: 8 November 2013

doi:10.1186/1546-0096-11-S1-A194

Cite this article as: Kraas et al:: OR11-005 - Mast cells respond to pathogen signals with IL-1ß. Pediatric Rheumatology 2013 11(Suppl 1):A194.

Submit your next manuscript to BioMed Central and take full advantage of:

- Convenient online submission

- Thorough peer review

- No space constraints or color figure charges

- Immediate publication on acceptance

- Inclusion in PubMed, CAS, Scopus and Google Scholar

- Research which is freely available for redistribution 